\title{
WATER IN BRITAIN
}




\section{WATER IN BRITAIN a study in applied hydrology and resource geography}

\section{KEITH SMITH BA, PhD}

Senior Lecturer in Geography in the University of Strathclyde 
ISBN 978-1-349-01499-6 ISBN 978-1-349-01497-2 (eBook) DOI 10.1007/978-1-349-01497-2

(C) Keith Smith 1972

Softcover reprint of the hardcover 1st edition 1972 978-0-333-13552-5

All rights reserved. No part of this publication may be reproduced or transmitted, in any form or by any means, without permission.

First published 1972 by

THE MACMILLAN PRESS LTD

London and Basingstoke Associated companies in New York, Toronto, Dublin, Melbourne, Johannesburg and Madras

SBN 333135520 


\section{Preface}

Geographers have always been concerned with the changing relationships between the physical world and human activity, but it is only relatively recently that a really critical awareness of the earth's environment as a natural resource has emerged. Within the last ten years, however, there has been a rapidly growing interest in water resources which has been stimulated by events such as the inauguration of the International Hydrological Decade in 1965 and the passing of the 1963 Water Resources Act for England and Wales. Most university degree courses in geography now include some study of hydrology and its applications in terms of water supplies, and geographers have joined other specialists in researching into these fields. But, despite the abundant opportunities for co-operative efforts, there has been too little linkage between the physical and human spheres of the discipline.

The purpose of this book, therefore, is to present for the first time an integrated water resource geography of the British Isles. Throughout, an attempt is made to bring together the results of recent research in a number of fields in order to relate the physical occurrence and natural variability of water to the social environment and the increasing demands being made upon this most fundamental resource. Following a brief discussion of basic principles, the origins and growth of the current water situation are traced through time. Methods of measuring the resources are outlined next, and this leads on to a systematic analysis of the factors influencing water availability, including floods and droughts. The maldistribution, and often conflicting nature, of water need is then described for each of the major supply sectors, and attention is drawn to the significance of water quality in relation to utilisation. Finally, regional water problems are considered together with some possible solutions.

Other authors may well have adopted a different balance between the hydrological and the water development aspects, but I have tried 
to maintain what is, I hope, an acceptable emphasis. Similarly, whilst I have attempted to avoid the dangers of over-compression which inevitably arise in any comparatively short book, a number of systematic texts, not specifically referred to in the book itself, are listed as a guide to further reading in an appendix. It was originally intended to use SI units only, but English equivalents have been added both in the text and on illustrations as an aid to clarity. In all cases precedence has been given to the metric values.

It is hoped that this volume will provide a sound introduction to geographers who are seeking, either through systematic courses based on hydrology or regional studies of Britain, some information on the current water situation in this country. This book should also have relevance for students at various levels in associated fields such as civil engineering, economics, biology or regional planning. Hydrologists and other professional personnel in the water industry may find this a convenient background in which to place the realities of every-day practice, whilst the interested layman - should he exist may discover some of the facts and implications which lie behind the newspaper headlines proclaiming a semi-permanent water crisis. 
To Fiona and Matthew 


\section{Contents}

Preface v v

List of Tables $\quad$ xi

Acknowledgements xiii

1 The Global Context 1

2 Historical Background 10

3 Hydrological Networks and Data 36

4 An Outline of British Hydrology 64

5 Floods and Droughts 100

6 Public Water Supply 126

7 The Non-domestic Demand for Water 148

8 Effluent Disposal and Pollution Control 168

9 Problems and Policies 188

Guide to Further Reading $\quad 218$

$\begin{array}{ll}\text { References } & 219\end{array}$

Name Index 233

Subject Index 236 


\section{List of Tables}

1 Percentage of annual precipitation (1956-60) associated with different synoptic types

2 Water balance at Harrogate according to the Thornthwaite and Penman methods

3 Percolation at Harrogate 1916-50

4 Comparative data for the Thames and the Tay

5 Percentage monthly incidence of extreme peak flows

6 Number and type of water undertakings in England and Wales in 1954 and 1970

7 Estimated average daily consumption per head in southeast England

8 Water consumption related to water heating systems in Bradford

9 Inter-industry variation in water use in south-east England 152

10 Areas of crops irrigated in a dry season in England and Wales

11 Minimum concentration of dissolved oxygen in the Tees estuary

12 Extent of water pollution in England and Wales in 1958 and 1970

13 Abstraction licences in force in the Trent River Authority area on 31 March 1969

14 Mean annual gross yield of resources

15 Licensed abstractions in England and Wales in 1969

16 Estimated growth of water deficiencies in south-east England 


\section{Acknowledgements}

My thanks are due to the many people who helped and advised me during the preparation of this book. I am especially grateful to the following for permission to reproduce the various illustrations stated below.

Editors of Periodicals: Journal of the Institution of Water Engineers, Figures 3.12, 4.9, 4.16, 5.4 and 9.1. Institute of British Geographers, Transactions, Figures 5.2 and 5.3. Tijdschrift voor Economische en Sociale Geografie, Figure 6.1.

Publishers: North-Holland Publishing Company, Amsterdam, Figure 4.4. Blackwells, Oxford, Figure 4.8. McGraw-Hill Publishing Co. Ltd., Figure 4.13. Institution of Civil Engineers, London, Figures 5.5, 5.6 and 7.2. Butterworths, London, Figure 8.1.

Official publications: The Controller, Her Majesty's Stationery Office (Crown Copyright Reserved) for Figures 3.1, 3.8, 4.1, 4.3, 4.12, 5.7, 7.1, 9.2, 9.3, 9.4 and 9.5. The Director, Institute of Geological Sciences for Figures 3.11 and 4.11. The Clerk to the Trent River Authority for Figure 8.2.

I must also record the practical assistance I received when writing this book at the University of Durham. In particular, I should like to thank Mr A. Corner of the Drawing Office, Department of Geography, University of Durham, who was responsible for drawing most of the illustrations. Finally, without the encouragement of my wife, this volume would never have been started.

KEITH SMITH

University of Strathclyde, Glasgow. 